\title{
Victims of crime: culture, politics and criminal process in the twenty-first century \\ MATTHEW HaLL ${ }^{1}$
}

University of Lincoln

\begin{abstract}
This paper sets out to marry three areas of concern to modern victimology. In the first instance the paper will explore the 'cultural turn' taken in our understandings of what it means to be a victim of crime in the twenty-first century. McGarry and Walklate (2015) characterise such 'cultural victimology' as comprising a wider sharing and reflection of individual and collective victimisation experiences, on the one hand, and, on the other, the mapping of those experiences through the criminal justice process. This paper will explore the interaction between such cultural understandings of victimbood and the political and policy forces which, since at least the late 1990s, have pledged to 'rebalance' the criminal justice systems of England and Wales and other jurisdictions to put victims 'at the heart' of those processes.
\end{abstract}

Keywords: victims; criminal justice; culture; victims policy; ideal victims

\section{Introduction}

$I^{n}$ $\mathrm{n}$ the early twenty-first century criminal victimisation is everywhere. From high-definition videos of the latest terrorist atrocities beamed into our homes, our phones and our laptops by 24 -hour news networks ${ }^{2}$ to the bite-size, personal, accounts from victims of crime, their families and their supporters appearing on our social media feeds. Under such conditions, members of the public can feel more personally connected with such instances of victimisation than at any time in recent history. Whether it be the collective outrage felt when terrorists strike at the 'heart of our democracy' 3 or a deep sense of personal empathy felt for the victims of historic sexual abuse coming forward to 'tell their stories', ${ }^{4}$ the notion of 'standing alongside' and showing 'solidarity' with the directly victimised is becoming ubiquitous in modern society. Under such conditions, public consciousness has become flooded with concepts like 'post-traumatic stress' and 'trauma'. At the same time, an

1 Lincoln Law School, University of Lincoln, Brayford Pool, Lincoln, LN6 7TS. Tel 01522835526. E-mail mahall@lincoln.ac.uk. Twitter: @profmatthewhall.

2 BBC, 'London Attack: Six Killed in Vehicle and Stabbing Incidents' BBC News (14 June 2017) <http://www.bbc.co.uk/news/uk-40146916>.

3 ITV, “This Is a Terrible attack at the Heart of our Democracy” - First Minister' ITV News (22 March 2017) <http://www.itv.com/news/wales/story/2017-03-22/this-is-a-terrible-attack-at-the-heart-of-ourdemocracy-first-minister $>$.

4 Ramona Alaggia, 'Many Ways of Telling: Expanding Conceptualizations of Child Sexual Abuse Disclosure' [2004] Child Abuse and Neglect 1213. 
increasingly informed public can engage like never before in detailed debates over how precisely such victims should be treated and what they should expect from the criminal justice process. In the flurry of such debates, opinions from members of the public on highly technical legal issues - such as the cross-examination of rape victims in court, compensation for victims of violent crime and the nature of 'consent' in sexual offences are now routinely juxtaposed with those of agents of the state, prosecutors, lawyers, politicians and professional scholars.

This paper sets out to marry three areas of concern to modern victimology. In the first instance the paper will explore the 'cultural turn' taken in our understandings of what it means to be a victim of crime in the twenty-first century. This paper will explore the interaction between cultural understandings of victimhood and the political and policy forces which, since at least the late 1990s, have pledged to 'rebalance' the criminal justice systems of England and Wales and other jurisdictions to put victims 'at the heart' of those processes. The paper will then move on to combine these two areas in seeking to expose some of the complications that exist when attempting to reconcile seemingly everexpanding understandings of victimisation with legal and procedural practicalities, especially within a still staunchly adversarial criminal justice system.

\section{Cultural victimology}

So-called 'cultural victimology' represents a relatively new direction taken in the victimological literature over recent years in an attempt to incorporate a number of features of the modern social, political and cultural landscape which both surrounds and permeates the notion of being a 'victim'. These features include the increasingly visual nature of social life and the symbolic displays of shared emotion that go along with this. In this context, the notion of 'standing alongside' victims of crime becomes more prevalent. Victims of crime (and their supporters) in turn provide increasingly public accounts of the harm they suffer. Cultural victimologists are also interested in the means by which the victimisation experience is mapped through the workings of the criminal justice system. Through such a process, public narratives concerning these experiences are developed, some of which become features of a shared cultural understanding about what it means to be victimised. In short, cultural victimology foregrounds suffering, how it is presented to society and what sense that society then makes of it. This reaches beyond standard critical victimology approaches to place emphasis on the nature of victimization itself in addition to the social standing of the person or group being victimised. ${ }^{5}$

At the forefront of this development, McGarry and Walklate ${ }^{6}$ characterise cultural victimology as broadly comprising two key aspects. These are the wider sharing and reflection of individual and collective victimisation experiences on the one hand and, on the other, the mapping of those experiences through the criminal justice process. I have previously drawn upon the work of Hans Boutellier, ${ }^{7}$ whose discussion of victimisation and morality in a secular society to some degree foreshadowed this trend. Boutellier argued that, as the process of secularisation goes on, common standards of morality decline but common appreciation of and sympathy for the impacts on those who have suffered harm remains and takes over as a shared moral barometer for society. In more recent parlance, we could say that such victimisation becomes incorporated into the fabric

5 Gabe Mythen and Will McGowan, 'Cultural Victimology Revisited: Synergies of Risk, Fear and Resilience' in Sandra Walklate (ed), Handbook of Victims and Victimology (2nd edn, Routledge 2017).

6 Ross McGarry and Sandra Walklate, Victims: Trauma, Testimony and Justice (Routledge 2015).

7 Hans Boutellier, Crime and Morality: The Significance of Criminal Justice in Post-Modern Culture (AA Dordrecht 2000). 
of our social culture. The author refers to this as the 'victimalization of morality'. Furedi in pioneering aspects of the cultural approach made a similar point in terms of social solidarity with victims in the UK context:

It is difficult to avoid the conclusion that, with British people feeling so fragmented, the ritual of grieving [for victims] provides one of the few experiences that create a sense of belonging. ${ }^{8}$

Central to this cultural approach to victimisation is an understanding of victimhood as a dynamic and developing concept, both in terms of society's understanding of it and the individual (or group) victim's personal experience. Significantly for the present discussion, if victimisation is now shared, defined and recognised as a matter of culture then recognition of 'victim status' becomes subjected to the ever-shifting contours of said culture. To illustrate this idea, we can look to the ongoing example from the UK of the Hillsborough Football Stadium disaster.

The Hillsborough disaster is the worst sporting-related tragedy in UK history. ${ }^{9}$ It followed a human crush in the overcrowded Western Stand (at the time a standing terrace) of the Hillsborough Football Stadium in Sheffield, England, during a 1989 Football Association Cup Semi-Final. Over 700 people were injured in the crush and 96 people all supporters of the Liverpool Football Club - lost their lives. In the days following the disaster, accusations quickly arose from those present, and then the families and supporters of those killed, that poor management of the situation by the presiding South Yorkshire Police Force had directly contributed, if not caused the tragedy. ${ }^{10}$ At the time, however, these concerns were played down in public discourse in favour of the police's version of events. This version included a number of accusations to the effect that the behaviour of the football supporters themselves had been the main contributor to the tragedy. These accusations against the supporters were most prominently taken up by The Sun newspaper, which was then and remains now Britain's most read newspaper. Four days after the tragedy The Sun ran with the front-page headline 'The Truth' followed by the sub-headlines: 'Some fans picked pockets of victims'; 'Some fans urinated on the brave cops'; and 'Some fans beat up PC giving kiss of life'. In the years that followed, those seeking to expose what they argued to be the gross negligence of the police and their vilification of the victims coalesced into a distinct movement - 'Justice for the 96' - organised by the Hillsborough Family Support Group. This group championed the perspective of the families of those killed and injured through an independent inquest in 1991 (which returned a verdict of accidental killing), the subsequent quashing of this panel's findings and an attempted private prosecution of the Chief Constable of South Yorkshire Police in $1998 .{ }^{11}$ Ultimately, as a result of this unceasing campaign, a second inquest began hearing evidence in 2014, with a jury of nine delivering verdicts in April 2016 to the effect that the 96 supporters had been 'unlawfully killed'. This jury also found that the supporters themselves bore no blame for the disaster. ${ }^{12}$ Following this verdict, the case was examined by the Crown Prosecution Service (CPS) which subsequently

8 Frank Furedi, 'A New Britain - A Nation of Victims' (1998) 35 Society 80, 82.

9 Phil Scraton, 'Policing with Contempt: The Degrading of Truth and Denial of Justice in the Aftermath of the Hillsborough Disaster' (1999) 26(3) Journal of Law and Society 273.

10 Ibid.

11 BBC, 'UK Hillsborough Private Prosecution Adjourned' BBC News (August 1998) $<$ http://news.bbc.co.uk/1/hi/uk/154680.stm>.

12 Mike Brennan, 'Closure for the 96? Sudden Death, Traumatic Grief and the New Hillsborough Inquests' in Neil Thompson, Gerry R Cox and Robert G Stevenson (eds), Handbook of Traumatic Loss: A Guide to Theory and Practice (Routledge 2017). 
pursued criminal charges against six individuals, including former Chief Superintendent, and match commander on the day, David Duckenfield.

The Hillsborough case exemplifies a great deal about the contemporary cultural context of victimisation and victim policy. The story of 'the 96' and their families is one of becoming victims in the eyes of the establishment and the public at large. The process by which this occurred has been frequently described as a 'journey'13 culminating in a public acknowledgment of this status by the Prime Minister after the 2016 verdict was announced. On this occasion, David Cameron commentated on the victims' 'long search for the truth'. ${ }^{14}$ The progression in the case from 1989 to 2016 is inherently interconnected with much wider social and cultural changes from a position in the late 1980s where deference to authority and to the media's presentation of 'facts', as well as basic trust in the police, was much more prevalent (as discussed by Garland). ${ }^{15}$ Furthermore, in 1989 the largely working-class football supporters and their families had very little platform to air their own grievances. More broadly, the victimisation experience in this case took on a wider cultural component as the city of Liverpool itself was increasingly seen as being vilified - especially after The Sun's headline - and its residents the collective victims of a still wider injustice. As noted by the chair of the Hillsborough Supporters Group following the announcement of the 2016 inquest verdict:

Let's be honest about this - people were against us. We had the media against us, as well as the establishment. Everything was against us. The only people that weren't against us was our own city. That's why I am so grateful to my city and so proud of my city. They always believed in us. ${ }^{16}$

The cultural narrative of a city beset as a collective victim is epitomised by the continued virtual boycott of The Sun newspaper in Liverpool. ${ }^{17}$ This notion that victimisation is no longer an 'individual' experience, but in many cases transcended the direct (or even indirect) victims to include still larger groups within society is a key feature of victimology's cultural turn.

This development of cultural victimology now challenges victimologists to reconsider some of our most entrenched assumptions about our subject matter. For example, few conceptualisations of victimisation and the relationship between victimisation, public policy and criminal justice reform have been more influential than that of Nils Christie's widely referenced discussion of 'ideal victims'. ${ }^{18}$ His argument was that some victims are endowed by the public and by policy-makers with 'ideal' status making them 'worthy' of public sympathy, accommodation, and facilitation of their rights through reform. Cultural victimology, however, has problematized this basic understanding of who is and who is not regarded as a genuine victim by focusing increased attention on the process of becoming recognised as a victim rather than assuming this as a static concept. Hence, the

13 Eleanor Barlow, 'Hillsborough Victim's Sister Captures Inquests Journey in Documentary' Liverpool Echo (Liverpool, 2 May 2016) <http://www.liverpoolecho.co.uk/news/liverpool-news/hillsborough-victims-sistercaptures-inquests-11273098>.

14 Prime Minister's Office, 'The Queen's Speech 2017: Background Notes' (21 June 2017) <https://www.gov.uk/government/uploads/system/uploads/attachment_data/file/620838/Queens_speec h_2017_background_notes.pdf $>$.

15 David Garland, The Culture of Control: Crime and Social Order in Contemporary Society (OUP 2001).

16 BBC, 'Hillsborough Inquests: Reaction to Unlawful Killing Conclusion' BBC News (26 April 2016) <http://www.bbc.co.uk/news/uk-england-36141858>.

17 Chris Horrie and Peter Chippindale, Stick It Up your Punterl: The Uncut Story of The Sun Newspaper (Faber \& Faber 2013).

18 Nils Christie, 'The Ideal Victim' in Ezzat A Fattah (ed), From Crime Policy to Victim Policy (Macmillan 1986). 
early characterisations of those hurt and killed at Hillsborough as 'football hooligans' gave way over time to a far more sympathetic public acceptance - and then official acceptance - of their victimised status. Significantly, most of the 96 killed at Hillsborough were young, ${ }^{19}$ able-bodied working-class men, ${ }^{20}$ some with criminal records. ${ }^{21}$ On the face of it these are not the ideal, vulnerable, victims of Christie's thought, but rather have become so (or recognised as so) over a long period of cultural shift in the public's overall impression of the police, its deference to authority figures and to the media in general.

Another pertinent example of shifting public - and perhaps cultural - understandings of victimhood revolves around the sufferers of historic sexual abuse at the hands of clergy of the Catholic Church and other historic child sex abuse cases. In the UK context McGarry and Walklate ${ }^{22}$ discuss the cultural relevance of revelations concerning noted television and radio celebrity Jimmy Savile, that is, that he was engaged in a decades-long campaign of persistent sexual abuse against some 300 victims aged between five and 75 years old. Such revelations have forced a cultural confrontation in the UK with the victims of these crimes, so long dismissed by the authorities and by public organisations like the $\mathrm{BBC}^{23}$ and the NHS. ${ }^{24}$ Whereas the public narrative in this case was once one of '(possibly) dirty old man', 'rascal' and 'celebrity', 25 the public narrative is now one of 'abuse', 'exploitation and 'violence': as of course, it has been for the victims all along. In both the Catholic Church cases and the Savile cases, victims were usually met with disbelief initially and have won recognition over decades only though a long-term campaign in the context of changing attitudes about religion and celebrity. Practically, the length of time since many of these events occurred has inevitably frustrated efforts to now bring the perpetrators to justice: raising the key question of how such cultural, constructivist, notions of victimhood interact with the more positivist criminal justice process. This will be a key question returned to in the last third of the present paper.

For their part, McGarry and Walklate 26 tie the increased recognition of 'less ideal victims' back to the growing importance of 'trauma' in victimological understandings, and the recognition that even 'non-ideal' victims whom we would not ordinarily consider vulnerable can suffer from this. The recent resurgence of 'trauma' as a concept in victimology reflects the fact that, as a condition, trauma develops over time and in directions many steps removed from the initial act (criminal or otherwise) that initiated the victimisation. ${ }^{27}$ Trauma can also be amplified or sustained by actors well beyond the specific criminal perpetrator in a given case. So-called 'secondary victimisation' at the

1978 were under 30 years old.

20 BBC, 'Hillsborough Inquests: The 96 Who Died' BBC News (26 April 2016) <http://www.bbc.co.uk/news/uk-26765007>.

21 'The Class Contempt that Killed 96' Socialist Worker (London, 18 September 2012) <https://socialistworker.co.uk/art/29084/The+class+contempt+that+killed+96>.

22 McGarry and Walklate (n 6).

23 Henry Mance, 'BBC Condemned for "serious failings" over Jimmy Savile' Financial Times (London, 2 June 2016) < https://www.ft.com/content/71e70c96-dba5-11e5-9ba8-3abc1e7247e4>.

24 Edward Malnick and Tim Brooks-Pollock, 'Jeremy Hunt Apologises for Jimmy Savile's "Sickening" Abuse in Hospitals' The Telegraph (London, 26 June 2014) < http://www.telegraph.co.uk/news/uknews/crime/jimmysavile/10928753/Jeremy-Hunt-apologises-for-Jimmy-Saviles-sickening-abuse-in-hospitals.html>.

25 See Fred Furedi, Moral Crusaders in an Age of Mistrust: The Jimmy Savile Scandal (Palgrave 2013) and Thomas Walz, 'Crones, Dirty Old Men, Sexy Seniors: Representations of the Sexuality of Older Persons' (2002) 7(2) Journal of Aging and Identity 99.

26 McGarry and Walklate (n 6).

27 Daniel Formolo, Laila van Ments and Jan Treur, 'Adaptive Modelling of Trauma: Development and Recovery of Patients’ (2016) 88 Procedia Computer Science 512. 
hands of the criminal justice system is a case in point, but so too is the ongoing treatment of victims by support services, local communities and the media. As an illustration, McGarry and Walklate ${ }^{28}$ draw on the story of Doug Beattie, an English solider and decorated Afghanistan veteran who opened up about his personal and emotional struggles both during and after the conflict. More recently, families of UK soldiers killed in the second Iraq war threatened to mount legal action if the delayed 'Chilcot Report' of the independent inquiry into to the reasons the UK entered the war did not get an official publication date, arguing that their family members were 'victims' of the conflict and, possibly, of deception by the UK government. ${ }^{29}$ The key point is that, as archetypal (often) masculine figures, soldiers usually lack the traditional characteristics of overt 'weakness' attributed to ideal victims.

A telling aspect of these examples is not just how 'victim status' or 'ideal victim status' is ascribed, but how they suggest a need to acquire this status not just through prolonged trauma, but also through sustained effort. It is almost impossible to imagine that the 96 Hillsborough victims and their families would have received the recognition they now have (with the tangible possibility of 'justice') without the consistent and organised efforts of the Hillsborough Family Support Group, not to mention a multitude of other supporters, lawyers, academics, investigators and so on. In the case of Doug Beattie it was the telling of his story via the publication of his biography that 'won' him recognition as having been 'truly' victimised.

Gaining victim status is one thing, but keeping it in the modern cultural context is quite another. Further to the above points, cultural understandings and recognition of victimisation may often appear fickle. One key example of this can be drawn from the case of Kate and Gerry McCann who, over the course of the decade since the disappearance of their daughter Madeleine from a Portuguese holiday resort, have been painted both as villains and victims. Thus, in late 2007 articles began appearing branding the McCanns and their friends (whom the media labelled 'the tapas seven') as 'swingers'. 30 Accusations of inconsistencies in the McCanns' story developed into theories, without corroborating evidence, that Madeleine had died through some misadventure in the family's apartment and that the alleged 'kidnapping' was a means of covering this up. The McCanns themselves were for a time given the status of arguidos (official suspects) by Portuguese investigators. ${ }^{31}$

Nevertheless, in the light of accusations which might have destroyed any sense of public, let alone official, goodwill to the couple, the McCanns have maintained a significant media presence throughout the period that has kept them, for the most part, on the sympathetic side of public/cultural discourse, securing intervention by Scotland Yard to the tune of a $£, 10$ million investigation. ${ }^{32}$ Indeed, it has often been commented that the McCanns have approached their situation in a way that is very media savvy,

28 McGarry and Walklate (n 6).

29 Rose Troup Buchanan, 'Chilcot Inquiry: Iraq Solidiers' Families Threaten to Sue as No Publication Date in Sight for Report' The Independent (London, 13 August 2015) < http://www.independent.co.uk/news/uk/iraqwar-inquiry-live-families-threaten-to-sue-as-no-publication-date-in-sight-for-chilcot-10452980.html $>$.

30 Martina Smit, 'Madeleine McCann Witness Breaks her Silence' The Telegraph (London, 14 December 2007) <http://www.telegraph.co.uk/news/worldnews/1572560/Madeleine-McCann-witness-breaks-hersilence.html>.

31 Helena Machado and Filipe Santos, 'The Disappearance of Madeleine McCann: Public Drama and Trial by Media in the Portuguese Press' (2009) 5(2) Crime, Media, Culture 146.

32 BBC, 'Madeleine McCann Investigation 'cost $£_{10}$ Million to Date' BBC News (17 September 2015) <http://www.bbc.co.uk/news/uk-34278538>. 
exploiting all the advantages of being middle-class, articulate professionals. ${ }^{33}$ Interesting comparisons were initially drawn with the case of Shannon Matthews, a nine-year-old girl who disappeared from her home in Dewsbury, West Yorkshire, in February 2009, some two years after the McCann disappearance. ${ }^{34}$ Media attention continued to be poured on the McCann case at the time, with relatively little attention paid to the Matthews case. The Matthews were a low-income working-class family who appeared far less capable of courting media attention. Notwithstanding the fact that, ultimately, it emerged Shannon's disappearance was orchestrated by her own mother and her boyfriend as a means of generating income thorough the publicity, the case still highlights that winning and retaining victim status for some requires both effort and social capital. It is in itself very telling of the cultural status of such victimisation in twenty-first-century Britain that Shannon's mother and boyfriend reached the conclusion (no doubt inspired by the McCann case) that this would be a workable means of gaining finance.

As the above examples illustrate, it has become impossible to approach the question of how cultural attitudes to victimisation change and adapt over time without discussing media representations and, most significantly, the role that social media has exerted in this sphere. Whilst work on the portrayal of crime and criminal justice in the media has been pursued for a long time and by a range of scholars, 35 the interactive and up-to-the-minute nature of so much of this media now increases its impact tenfold. It is not, however, just the recognition of victimisation by the media or by the public in general that changes over time. In reality victims themselves may only come to recognise their own victimisation after a period of reflection, and in most cases their thoughts and ideas about that victimisation will develop as time goes on. ${ }^{36}$ Again, such development is part-and-parcel of modern understandings of 'trauma'. ${ }^{37}$ Victimisation is therefore a dynamic process both personally as well as publicly and culturally. Those studying victimology have themselves been slow to adapt their methodologies to incorporate this dynamic nature of victimisation. Indeed, Shapland and Hall's 2007 extensive review of what we know about the effects of crime on victims indicated a marked lack of victimisation studies which incorporated any longitudinal component. ${ }^{38}$ In this next section, this paper will move on to discuss how this newly acquired appreciation for the cultural aspects of victimisation has impacted upon public policy.

\section{Victim culture and victim reform}

In 2017, the basic proposition that victim policy, like criminal justice policy as a whole, is intricately bound up with the political aspirations of different governments, parties and other groups, rather than representing some 'pure' or paternalistic philosophy of assisting victims of crime, has become somewhat prosaic. The difficulty with such a proposition when viewed in isolation is not that it is wrong, but rather that it offers little by way of explanation for why certain victims, victimisations and reform agendas appear to gain

33 Owen Jones, Chavs: The Demonization of the Working Class (Verso Books 2012).

34 Janet Cotterill, 'Mugshots and Motherhood: The Media Semiotics of Vilification in Child Abduction Cases' (2011) 24(4) International Journal for the Semiotics of Law-Revue internationale de Sémiotique juridique 447.

35 Christopher Birbeck, The Oxford Handbook of Media Representations of Crime and Criminal Justice (OUP 2014).

36 Joanna Shapland and Matthew Hall, 'What Do We Know about the Effect of Crime on Victims?' (2007) 14(2) International Review of Victimology 175.

37 See Matthew Stimmel, Keith Cruise, Julian Ford and Rebecca Weiss, 'Trauma Exposure, Post-traumatic Stress Disorder Symptomatology, and Aggression in Male Juvenile Offenders. Psychological Trauma: Theory, Research' (2014) 6(2) Practice and Policy 184.

38 Shapland and Hall (n 36). 
momentum in public discourse and public policy whilst others do not. True, one can begin to add a greater degree of substance to this position by noting the ideological and economic drivers that push government policy as a whole. Hence, one might argue that governments of all shades and hues in the UK have since at least the turn of the century rarely detracted from policies which broadly support neoliberal, market-based ideologies. ${ }^{39}$ Under this construction, we might explain the advent of different victim polices largely by reference to their capacity to generate efficiency in the criminal justice system, even if this comes at the cost of increased punitiveness and/or the prioritisation of crime control over due process. Victims therefore become significant from a policy perspective largely because it is recognised that a criminal justice system - certainly an adversarial criminal justice system - needs their support in order to run effectively.

Certain theorists have added another level of conceptual depth to the above basic propositions. Hence, Garland incorporates this use of victims as a tool for buttressing confidence in, and thus effectiveness of, the criminal justice process within a broader 'culture of control' which he argues permeates through politics and public policy in late modernity. ${ }^{40}$ Whilst such macro perspectives are extremely illuminating, again they are not tailored to facilitating a closer inspection of which specific victims are actually benefiting (or not) from this increased attention, nor do they conceptualise the processes through which this comes about. For many years, the customary victimological answer to these outstanding questions has been that the policy direction described above inevitably becomes centred around 'ideal' victims, because it is these victims who attract public sympathy and are thus the most advantageous for a political party also seeking to gain votes. Usually, such victims are conceptualised in abstract terms that have not progressed a great deal from those described by Christie in 1986, as discussed above. Indeed, the phrase 'ideal victim' is often used in a rather offhand way by victimologists, betraying a confidence that we know who these people are, that their characteristics are largely established and that we can pinpoint the forms of victimisation to which they are most often associated. Critical criminologists in turn added detail to this picture, arguing that the identification of these so-called 'ideal victims' was far from objective and in fact reflected deeply ingrained power inequalities within society. Once again, however, this macro-level view tends to obscure the specific mechanics by which certain victims are promoted up the political hierarchy.

From the discussion of cultural drivers presented in this paper, it can now be confidently asserted that the more traditional perspectives encapsulated within the previous paragraph are limited in the contemporary context. In reality, however, what the cultural victimological approach reveals is the means by which the victims who actually benefit from the attention of policymakers (or at least are supposed to) is strongly influenced by the ebbs and flows of prevailing cultural attitudes. More specifically, this process seems to be driven by the production and reproduction of narratives around different kinds of victimisation (or harm) that become more or less culturally pervasive over time and, in so doing, generate what this paper will call 'victim capital'.

It is these cultural narratives on the nature and impact of victimisation, rather than a fixed notion of ideal victimhood, which I suggest policymakers are in fact responding to. To illustrate how this process operates I will here focus on three key example - rape, child sexual exploitation (CSE) and terrorism - as broad categories of victimisation-types which have been subjected to prolonged cultural scrutiny, shifting public understandings

39 Henry A Giroux, Against the Terror of Neoliberalism: Politics beyond the Age of Greed (Routledge 2015).

40 Garland (n 15). 
and constructions, resulting in the advent of greater victim capital which in many cases has been translated into public policy and reform.

\section{VICTIMS OF RAPE}

One of the clearest examples from England and Wales in recent years of an apparently heightened cultural resonance surrounding a particular group of victims is that associated with victims of rape. Of course, many victimologists would rightly assert that, since the mid-1990s, rape victims had already achieved a degree of cultural and political prominence hitherto unknown in criminal justice circles. ${ }^{41}$ Rape victims have long been held up as the archetypical invisible and mistreated victim of crime. ${ }^{42}$ Indeed, the development of modern victimology itself owes much to an initial focus on such victimisation and the difficulties faced by rape victims on approaching the criminal justice system. This development was driven in particular by feminist commentators. ${ }^{43}$ Notwithstanding this background, however, it is argued that the increasing cultural resonance now associated with rape victimisation in more recent years - protracted through the lens of social media and 24-hour news coverage - has rendered contemporary levels of public commentary and debate largely unprecedented. This is especially the case in relation to the position of rape victims within the criminal justice process itself.

In the shorter term, much of this renewed public interest appears to have been brokered in England and Wales by the considerable public and media attention given to the case of Chedwyn Michael 'Ched' Evans. Evans was a Premier League footballer initially convicted in 2012 of raping a 19 -year-old woman ${ }^{44}$ who was at that point deemed too drunk to consent. Many supporters rallied to his defence. ${ }^{45}$ Many more were quick to condemn a criminal justice process which granted victim status to the woman in question. Indeed, some of the public comments on the matter harked back to debates concerning victim precipitation/blaming ${ }^{46}$ whilst also questioning the legal status of 'drunken' consent: which in the UK criminal law has been fairly clear since the case of $\mathrm{R} v$ Bree $e^{47}$ in 2007. Some commentators saw a positive side to this in that, for them, the strong public reactions to the case reflected a criminal justice system that had become more willing to tackle 'difficult' cases and also indicated that juries were now more willing to put aside victim-blaming attitudes and myths about rape. ${ }^{48}$ Whatever the interpretation, it is clear that this case exemplifies how victim status is now caught up in social culture and protracted through social media platforms. This final point was emphasised by Duggan

41 Jennifer Temkin, Rape and the Legal Process (2nd edn OUP 2002).

42 Menachem Amir, Patterns in Forcible Rape (University of Chicago Press 1971).

43 Sue Lees, Carnal Knowledge: Rape on Trial (2nd edn Women's Press 2002).

44 See R $v$ Ched Evans (Chedwyn Evans) [2012] EWCA Crim 2559.

45 Grace Dent, 'Ched Evans' Fans Continue to Defend Him, but Would They Do the Same for a Rapist Cab Driver?' The Independent (London, 5 January 2017) <http://www.independent.co.uk/voices/comment/ football-clubs-might-turn-a-blind-eye-to-rape-but-while-ched-evans-supporters-still-run-a-website9958981.html>.

46 Jennifer Agate and Jocelyn Ledward, 'Social Media: How the Net is Closing in on Cyber Bullies' (2013) 24(8) Entertainment Law Review 263.

47 [2007] EWCA Crim 804.

48 Joan Smith, 'The Ched Evans Case Shows Rape Victim-blamers are Getting Scared' The Guardian (London, 16 January 2015) <https://www.theguardian.com/commentisfree/2015/jan/16/ched-evans-rape-victimblamers>. 
and Heap as contributing to what they term the 'administrating' of victimisation in twenty-first century Britain. ${ }^{49}$

It was in such a social and cultural context that when the Criminal Case Review Commission (CCRC) of England and Wales received a referral of the case by Evans' new legal team in 2015, it chose to fast-track the case, stating:

... in line with our published policy on prioritisation, and in relation to the facts of the case and the issues raised in Evans' application to us ... we now expect our substantive investigation to begin within the next few weeks. ${ }^{50}$

The CCRC referred the case for reconsideration by the Court of Appeal in October 2015 and the court ordered a retrial in March 2016, on the grounds that the trial judge had erred in law in excluding evidence of the complainant's sexual history. In this second trial, Evans was acquitted.

For present purposes, what is particularly noteworthy about the conviction and subsequent acquittal of Ched Evans is the impact this appears to have had not only on public discourse, but also in relation to concrete reform agendas emanating from major political parties. Indeed, the degree of significance associated with the Evans case can be appreciated through examining an open letter sent to the Labour MP Harriet Harman from the Criminal Bar Association in March 2017. In that letter, the Bar bemoaned the apparent influence the case was exercising over public debate:

Continued references to the Ched Evans case as an example of what 'typical' cases involve are wholly misleading; it was an unusual case that turned on an unusual set of facts. It was on the peculiar circumstances of that case that the judicial decisions were made. ${ }^{51}$

Specifically, the Association was seeking to criticise an amendment to s 41 of the Youth Justice and Criminal Evidence Act: a so-called 'rape shield' provision which purports to limit the cross-examination of witnesses on their sexual history. The amendment, which had been proposed by Harman as part of the Prisons and Courts Bill then going through Parliament, would have effectively banned all sexual history questioning in court without the exceptions and discretions the law presently entails. ${ }^{52}$ This tabled amendment followed the introduction of a separate Private Member's Bill a few weeks before - set out by Liz Saville Roberts MP of Plaid Cymru - which proposed a different reform to the rape shield, retaining certain discretionary exceptions.

In the end, both proposals ran out of parliamentary time following the call of an unexpected snap general election in the UK in May 2017. It is nevertheless extremely telling of the degree of victim capital rape victims have recently acquired in the contemporary cultural context that it drove two distinctly different calls for reform in the space of one month: s 41 having existed on the statute books and operated since 1999. Indeed, we might conceptualise this situation as one of two competing narratives concerning what such victims 'need' from the criminal justice system, each vying for cultural predominance. ${ }^{53}$

49 Marian Duggan and Vicky Heap, Administrating Victimization: The Politics of Anti-Social Behaviour and Hate Crime Policy (Palgrave 2014).

50 BBC, 'Ched Evans: Investigation into rape conviction fast-tracked' BBC News (19 October 2015) <http://www.bbc.co.uk/news/uk-29679563>.

51 Criminal Bar Association of England and Wales, 'Open Letter to Harriet Harman MP' (27 March 2017) <https://www.clsa.co.uk/index.php?q=clsa-cba-open-letter-to-harriet-harman-mp-28th-march-2017>.

52 Matthew Hall, Victims and Policy Making: A Comparative Perspective (Willan 2010).

53 Petrus C van Duyne, A Psychological Approach to Differences in Sentencing (Netherlands Ministry of Justice 1981). 
Returning to the Criminal Bar Association's letter, the criticism made in the above extract is essentially that both activists and MPs had presented the Evans case as a 'typical' narrative of rape trials, a narrative the Association claimed was misleading. What is especially telling is the level of concern expressed about inaccurate representations of the Evans case as 'precedent' and how this might impact upon public sensibilities on the issues:

Sadly, the previously mentioned characterisation of the judgment as a 'precedent', coupled with incautious public remarks (that the law was being set back by decades) appear designed more to alarm than inform. We are concerned that this is a trend set to continue in light of recent reports and comments made on social media. 54

From a cultural perspective then we might characterise the Bar's concerns as centred around the public narrative forming around this case and its implications for the criminal justice system: namely, a shift in policy, engendered by growing victim capital, to initiate a change in the evidential rules. For many commentators, especially those representing the legal profession, further restrictions on the use of sexual history evidence can only prejudice defendants' ability to have a fair trial. ${ }^{55}$ In this example then we see not only the influence of such cultural narratives and the degree of victim capital it may command, but also the potential dangers of this influence: especially when this appears to be based in part on misinformation or incomplete understanding.

Another aspect of the developing public conversation on the place of rape victims in the criminal justice system of England and Wales has revolved around so-called 'victim blaming' by the judiciary. This came to the fore in March 2017 when a retiring senior circuit judge in Manchester, Judge Lindsey Kushner, used her sentencing remarks in her final trial to advise/warn women that excessive drinking might enhance their vulnerability to victimisation:

I don't think it's wrong for a judge to beg women to take actions to protect themselves. That must not put responsibility on them rather than the perpetrator. How I see it is burglars are out there and nobody says burglars are OK but we do say: 'Please don't leave your back door open at night, take steps to protect yourselves. ${ }^{, 56}$

The judge continued:

It should not be like that but it does happen and we see it time and time again. ${ }^{57}$ She added:

They are entitled to do what they like but please be aware there are men out there who gravitate towards a woman who might be more vulnerable than others. ${ }^{58}$

The trial in question had involved a 19-year-old woman who was attacked and raped by a man she met in a fast food restaurant. The victim had spent the evening drinking beer and vodka during a night out in Manchester. It is notable that this 'warning' issued by the judge was couched in careful terms which appear to try and avoid the charge of victim

54 Criminal Bar Association (n 51) 2.

55 Andrew Ashworth, 'Victims' Rights, Defendants' Rights and Criminal Procedure' in Adam Crawford and Jo Goodey (eds), Integrating a Victim Perspective within Criminal Justice: International Debates (Ashgate 2000).

56 Kevin Rawlinson, 'Judge Accused of Victim-blaming in Comments on Rape Case' The Guardian (London,10 March 2017) < https://www.theguardian.com/society/2017/mar/10/judge-accused-of-victim-blamingduring-sentencing-comments-in-case $>$.

57 Ibid, unpaginated.

58 Ibid, unpaginated. 
blaming. Nevertheless, the speech was emphatically interpreted as such by Rape Crisis ${ }^{59}$ and also, notably, by Dame Vera Baird, the Police and Crime Commissioner for Northumbria. ${ }^{60}$ Baird, for her part, had been responsible for commissioning a 2016 study of rape trials by Durham et $\mathrm{al}^{61}$ which led to the introduction of the Private Member's Bill by Liz Saville Roberts MP concerning rape shield laws discussed above. Around the same time, a Canadian case gained international notoriety after a judge allegedly told a complainant in a rape trial to 'keep her knees together'. ${ }^{2}$ Prior to this, in 2015 another judge in England sparked anger after branding a rape victim 'extremely foolish' for drinking too much before she was attacked outside a nightclub. ${ }^{63}$

This narrative of judges 'abusing' rape victims in court has therefore built up a cultural pedigree over time. In the Kushner case it is significant that the victim later came forward to express her support for the judge's comments. In so doing the victim indicated that, whilst she had initially felt a sense of self-blame for the incident, she had come to realise it was not her fault, although she continued to think that women who had been drinking would be less likely to be believed. ${ }^{64} \mathrm{~A}$ few months after this case was reported, Ched Evans in an interview with The Times newspaper himself offered the view that 'women need to be made aware of the dangers they can put themselves in because there are genuine rapists out there who prey on girls who have been drinking'. ${ }^{65}$ The choice by Evans to speak out on this issue was met with palatable cynicism by many commentators, but the episode does serve to reinforce the cultural impact of such cases and figures in the twenty-first century.

Another related development coming in late 2016 was the publication of a report into the piloted use of pre-recorded cross-examination in certain participating Crown Court centres. ${ }^{66}$ The results of that study appeared broadly favourable to the wider use of this special measure in the future. Still in the wake of the ongoing public debates about sexual history and victim blaming in rape cases, the Lord Chancellor appeared to announce soon afterwards that the government would be accelerating the rollout of pre-recorded crossexamination to all courts for use in rape cases. The press release stated:

New measures that will spare rape victims the trauma and inconvenience of attending court hearings will be rolled out across the country from September. Victims of rape and other sex crimes will have their cross-examination evidence pre-recorded and played during the trial. Originally the rollout was not due to

59 BBC, 'Retiring Judge Lindsey Kushner Issues Drunk Women Rape Warning' BBC News (London, 10 March 2017) <http://www.bbc.co.uk/news/uk-england-manchester-39233617>.

60 Ian Robson, 'Police Commissioner Vera Baird Blasts Judge over Comments on Drunk Rape Victims', ChronicleLive (Newcastle12 March 2017) <http://www.chroniclelive.co.uk/news/north-east-news/policecommissioner-vera-baird-blasts-12729523>.

61 Ruth Durham, Rachel Lawson, Anita Lord, and Dame Vera Baird, Seeing is Believing: The Northumbria Court Observation Panel Report on 30 Rape Trials 2015-2016 (Office of the Police and Crime Commissioner for Northumbria 2016).

62 Ashifa Kassam, 'Canada Judge Resigns over "Keep your Knees Together" Comment in Rape Trial' The Guardian (London, 9 March 2017) <https://www.theguardian.com/world/2017/mar/10/canada-judgeresigns-keep-your-knees-together-comment-rape-trial>.

63 Martin Evans, 'Judge Brands Rape Victim “foolish” for Drinking Too Much' The Telegraph (London, 13 February 2015) <http://www.telegraph.co.uk/news/uknews/crime/11411745/Judge-brands-rape-victimfoolish-for-drinking-too-much.html>.

64 'Rape Victim Says Judge Was Right to Say She Put Herself in Danger by Being Drunk' The Independent (London, 28 March 2017) <http://www.independent.co.uk/news/uk/crime/rape-victim-megan-clarkmanchester-drunk-danger-judge-judge-lindsey-kushner-crown-court-responsible-a 7653341.html>.

65 Ibid.

66 John Baverstock, Process Evaluation of Pre-recorded Cross-examination Pilot (Section 28) (Ministry of Justice 2016). 
begin until next year but will now start in September after Justice Secretary

Elizabeth Truss and senior judges agreed to accelerate the scheme. ${ }^{67}$

Significantly, this announcement was met with the unusual step of the Lord Chief Justice writing a public letter to senior judges essentially criticising and explicitly correcting the impression that the Lord Chancellor had given in the press release. In the letter, Lord Thomas acknowledges the success of the pilots, but points out that they were limited to vulnerable witnesses falling under s 16 of the Youth Justice and Criminal Evidence Act, who are mainly children. This does not automatically include victims of rape, who qualify as 'intimidated' witnesses under s 17(4). The letter indicates that the pilot will indeed be extended to other courts, although only on a 'carefully phased basis' which will 'inevitably take some time'. He also notes that this pilot will be restricted to s 16 witnesses. The letter goes on to indicate that the judiciary has agreed with the Ministry of Justice to extend piloting of pre-recorded cross-examination to s 17(4) rape victims only in the original three pilot areas and that 'this new pilot will have to be evaluated and no decision has yet been made as to expansion of these provisions to other court centres'.

This interaction between the Ministry of Justice and the judiciary, played out in public and disseminated via social media, demonstrates both the cultural dimension of such policies in the twenty-first century as well as the multi-levelled governance and variety of stakeholders to those policies which will be the focus of the following section of this paper. It is also undoubtedly significant to note in this case the broader political context of the Lord Chief Justice's letter, coming as it did in the immediate wake of a perceived lack of support by the Lord Chancellor for the independence of the judiciary following heavy criticism by some media outlets of the judges (including Lord Thomas himself) when they ruled against the government in the High Court in the case of Miller. ${ }^{68}$ The case had concerned the executive's right to trigger Article 50 of the 1992 Maastricht Treaty on European Union without first consulting Parliament. ${ }^{69}$ This once again indicates that culture, politics, the media and victim policies are all heavily intertwined.

Overall, what we see in these events is a combination of mediated stories, disgruntlement at the judiciary and a relatively new level of empathy even for potentially 'less-ideal' rape victims coming together to enhance public sympathy and cultural meaning surrounding this form of criminal victimisation.

\section{VICTIMS OF CSE}

A related but to some extent even more profound shift in the cultural landscape has taken place over recent years concerning CSE in general, and historic cases of sexual abuse in particular. This paper has already noted how in England and Wales the Savile cases have instilled within public consciousness a new impression of sex offenders and the nature of sexual victimisation itself. Similar examples can also be drawn from further afield, notably in the US with the ongoing criminal cases against comedian Bill Cosby. ${ }^{70}$ In the light of

67 Ministry of Justice, 'Greater Protection for Rape Victims and Children at Risk of Grooming' (Ministry of Justice, 19 March 2017) <https://www.gov.uk/government/news/greater-protection-for-rape-victims-andchildren-at-risk-of-grooming $>$.

68 [2016] EWHC 2768 (Admin)

69 Gavin Phillipson, 'A Dive into Deep Constitutional Waters: Article 50, the Prerogative and Parliament' (2016) Modern Law Review. 79(6): 1064-89 <https://ssrn.com/abstract $=2873995>$ or http://dx.doi.org/10.1111/1468-2230.12230.

70 Clark Mindock, 'Bill Cosby: Judge Declares Mistrial after Jury Says it is "Hopelessly Deadlocked” in Sexual Assault Case' The Independent (London, 17 June 2017) <http://www.independent.co.uk/ news/world/americas/bill-cosby-trial-latest-judge-mistrial-norristown-pennsylvania-jury-deadlockeda7795066.html>. 
such cases, long-held cultural views, epitomised by symbolic pronouncements such as it was a different world then', have clearly lost cultural significance, whereas complainants themselves have gained it. In the process, we have witnessed the development of new narratives of risk associated with the power and influence endowed to 'celebrities'. Indeed, in many ways this represents an archetype example of a risk generated by modernity itself, as understood by Beck. ${ }^{71}$ Moreover, it is a risk that has forced not only the government and the criminal justice system to confront such victimisation, but also wider organisations including the NHS and the BBC, each of which having, to some extent, enabled abuses to continue. ${ }^{72}$

Child sexual abuse was further catapulted into public prominence by the so-called CSE abuse scandal in the Yorkshire town of Rotherham. Here, in 2010, five men were found guilty of a series of sexual offences against girls as young as 12. A subsequent investigation by The Times newspaper reported that the exploitation of children in the area was much more widespread, and the Home Affairs Select Committee criticised South Yorkshire Police Force and Rotherham Metropolitan Borough Council for their handling and covering up of the abuse. ${ }^{73}$ On 10 September 2014, the Secretary of State for Communities and Local Government, Eric Pickles, announced that an independent investigation would be held into whether Rotherham Council covered up information about the abuse. Led by Louise Casey, former Victims' Commissioner and now Director General of the government's Troubled Families Programme, the investigation looked into the council's governance, its services for children and young people, as well as its taxi and private hire licensing provisions. Casey's investigation found that the CSE team was poorly directed, suffered from excessive caseloads, and did not share information. ${ }^{74}$ Following the report's publication in February 2015, Pickles stated that the local authority was 'not fit for purpose'75 and announced proposals to remove control from the local councillors and give it to a team of five appointed commissioners, including one tasked specifically with looking at children's services. After the report's publication, files relating to a current councillor and a past councillor, identifying 'a number of potentially criminal matters', were passed to the National Crime Agency. The leader of the council, Paul Lakin, resigned, and members of the council cabinet also stood down. ${ }^{76}$

The Rotherham case has been instrumental in helping to project CSE into public consciousness. Indeed, the very acronym 'CSE', unknown to a large proportion of the public only a few years ago, has now become widely utilised in the UK context, especially on social media. The cultural narrative of 'cold' cases, usually involving child victims who have since grown into adulthood, has provoked particular attention. In many cases the narrative around these crimes - owing to their long-ignored nature - has revolved around the longer-term and developing trauma elements of the victimisation. Thus, one sees the trauma experienced by such victims frequently in the surrounding public policy rhetoric. It is within this cultural context that the CPS in 2015 constituted a dedicated Child Abuse Review Panel capable of

71 Ulrich Beck, Risk Society Towards a New Modernity (Sage 1992).

72 See above n 23 and n 24.

73 BBC, 'Rotherham Child Abuse: The Background to the Scandal' BBC News (5 February 2015) <http://www.bbc.co.uk/news/uk-england-south-yorkshire-28934963>.

74 Louise Casey, Report of Inspection of Rotherbam Metropolitan Borough Council (Department for Communities and Local Government 2015).

75 Martin Evans, 'Rotherham Council's Leadership Resigns Following Damning Child Sex Abuse Report' The Telegraph (London, 4 February 2015) <http://www.telegraph.co.uk/news/uknews/crime/ $11390001 /$ Rotherham-child-sex-abuse-scandal-council-not-fit-for-purpose.html $>$.

76 Ibid. 
revisiting decisions to drop such prosecutions on the behest of victims themselves. The significant decision to muddy (to a limited degree) the highly engrained operating principle of the CPS that its decisions are not subject to appeal and only account for, rather than prioritise, the views of victims illustrates the significance of the victim capital now afforded to such victimisation. This example also raises another cultural tendency developed over recent years of an apparent increased public willingness to question official determinations of victimhood, an issue to be returned to later in this paper.

\section{VICTIMS OF TERRORISM}

One of the most prevalent and impactful cultural shifts in recent decades concerning the meanings attributed to a specific form of victimisation has been the new degree of victim capital associated with terrorism. Terrorism has of course achieved a central place in social-political discourse since at least the 2001 attacks on the World Trade Centre in New York. Indeed, the cultural impact of terrorism on public consciousness has had broader impacts beyond terrorist cases themselves. Thus, the recent drive for reform to the Criminal Injuries Compensation Scheme in England and Wales was partly spurred on by the dissatisfaction of victims and relatives of victims who were injured or killed in the London bombings of July 2005. ${ }^{77}$ As argued by Mythen and McGowan:

It is precisely because the survivors of $7 / 7$ were party to an attack that deeply offended the moral sensibilities of 'ordinary people' that the UK government decided to increase compensation paid to victims. What is at play here is essentially a moral judgement about degrees of suffering, gauged in terms of cultural proximity and perceived psychological impact rather than a decision determined solely by physiological disability. Thus, victims of terrorism are culturally constructed as more important and deserving of sympathy than victims of other violent crimes, such as corporate homicide. Put bluntly, some victims are more equal than others. ${ }^{78}$

Mythen first raised these issues directly in relation to the development of cultural victimology in the following terms:

From here, the cultural construction of the terrorist threat in the UK is utilised as a way of tapping into the institutional tendency to use the figurehead of the victim as a way of organising and regulating social activity. Centring on the shaping of 'new terrorism', the chapter elucidates how cultural institutions play a major role in defining crime risks and circulating dominant ideas about victimisation. The example of 'new terrorism' is used to bring into view current debates about the 'risk society' and the generation of a 'culture of fear'. ${ }^{79}$

Under this increasingly mediatised construction of terrorism, the harm and suffering attributed to terrorist victims and their wider families has generated a sense of shared, cultural mourning (and trauma) around these kinds of crimes. From this, new victims' spokespeople ${ }^{80}$ have emerged. Amongst the most prominent in England and Wales is the figure of Brendan Cox, husband to murdered MP Helen Joanne Cox, who was shot and stabbed outside her constituency office in June 2016 in Birstall. What followed was a

77 Home Office, Rebuilding Lives: Supporting Victims of Crime (Stationery Office 2005).

78 Gabe Mythen and Will McGowan, 'Cultural Victimology Revisited Synergies of Risk, Fear and Resilience' in Walklate (n 5) 465.

79 Gabe Mythen, 'Cultural Victimology: Are We All Victims Now?' in Sandra Walklate (ed), Handbook of Victims and Victimology (Willan 2007) 470.

80 Duggan and Heap (n 49). 
significant public outpouring of grief and dismay at the loss of 'Jo'. 81 Although the assailant was convicted of murder rather than of terrorist offences, the case quickly became labelled as one of 'terrorism' in accordance with its technical definition under s 1 of the Terrorism Act 2000. Brendan Cox's extremely articulate and dignified responses (attributable in no small part to cultural capital) to the murder of his wife, delivered through the 24-hour news media (and, later, a book) became the target of great swathes of sympathy from a public who saw themselves as 'standing alongside' him. Jo Cox's position as an MP and therefore 'representative of the people' helped to cement this impression. Brendan Cox himself identified the 'public support' as a 'great help' following the murder. ${ }^{82}$

Significantly, the cultural approach to victimology would emphasise the sense of a public 'bearing witness' to this victimisation, especially thorough social media and 24hour television coverage. ${ }^{83}$ Indeed, in other cases of victimisation around the world the point has been reached where people thousands of miles away can bear witness to crimes in real time through the social media updates of those involved on the ground. A prominent case is that of Bana al-Abed, the seven-year-old girl who tweeted updates in the last weeks of the siege of Alleppo in Syria during 2016.84 The identification of the 'global community' with this little girl they had never met and indeed had very little in common with was borne out by the significant concern expressed around the world when her tweets abruptly ceased. More recently, one can also look to the tweeting of images from inside the main chamber of the House of Commons in Westminster during the lock-down of MPs during the March 2017 terrorist attack. ${ }^{85}$ In this latter case, it is notable that these public accounts of victimisation went unchallenged despite being technically against the usually strict rules against taking and uploading photos from within the chamber.

As was the case with Jo Cox, the Westminster attack - also labelled as a 'terrorist' incident - was 'witnessed' live through media reporting within minutes of it occurring and in the next few days hundreds of mobile phone-captured images and videos of the events as they occurred (over the course of 82 seconds on one Wednesday afternoon) were constantly broadcast. The four people who were initially killed during the attack were identified quickly and their faces adorned posters and walls of remembrance around the country and at hastily arranged public vigils. The cultural portrayal was one of an attack not just on individuals but on 'British democracy'. ${ }^{86}$ Out of the 50 people injured in the incident, it is notable that particular attention and public sympathy was directed at Andreea Cristea following the broadcast of a video of her being knocked off

81 Steve Corbett, 'The Social Consequences of Brexit for the UK and Europe: Euroscepticism, Populism, Nationalism, and Societal Division' (2016) 6(1) International Journal of Social Quality 11.

82 Mary Riddell, “'Shock Is the Only Thing that Keeps You Going': Brendan Cox on Life after the Death of his Wife, Jo' The Telegraph (London, 14 April 2017) < http://www.telegraph.co.uk/men/thinking-man/shockthing-keeps-going-brendan-cox-life-death-wife-jo/>.

83 McGarry and Walklate (n 6).

84 Caitlin Gibson, 'How a 7-Year-Old Aleppo Girl on Twitter Became our Era's Anne Frank' Washington Post (Washington, 6 December 2016) <https://www.washingtonpost.com/lifestyle/style/how-a-7-year-oldaleppo-girl-on-twitter-became-our-eras-anne-frank/2016/12/06/b474af5c-bb09-11e6-91ee1adddfe36cbe_story.html?tid=a_inl\&utm_term $=.65779455 \mathrm{bbc} 0>$.

85 In which the perpetrator drove a car onto the pavement on Westminster Bridge outside the Houses of Parliament, killing four people and then stabbing and killing a police officer stationed at Parliament.

86 Lizzie Dearden, "Theresa May Speech in full: Prime Minister says London Terror Attack suspect "tried to silence our democracy" The Independent (London, 23 March 2017) <http://www.independent.co.uk/news/uk/home-news/theresa-may-london-terror-attack-speech-in-fullsuspect-british-born-silence-democracy-mi5-a7645491.html>. 
Westminster bridge into the River Thames during the attack. She died from multiple organ failure in hospital some days later to become the sixth fatality associated with the event, including the perpetrator himself. Again, through such means the public were able to bear witnesses to Cristea's victimisation in particular and in a very direct way. Returning to Brendan Cox, his status as something of a voice of those affected directly by terrorism was borne out by his frequent media coverage after the Westminster incident, including during the 2017 general election, when all the major parties agreed to suspension of campaigning for one afternoon as a token of respect to the murdered MP.

The collective unity shown after terrorist incidents in different cities - the notion that the residents of those cities are collectively victimised - points to another prominent feature of cultural victimology: greater deference to the concept of mass victimisation. Previously, we have noted the impression of a city beset as a cultural victim epitomised by the boycott of The Sun newspaper in Liverpool ${ }^{87}$ following that paper's reporting of the Hillsborough disaster. Indeed, in a recently published editorial one 30-year-old citizen of Liverpool, who was two years old at the time of the disaster and has no direct relation who was there, reflects on how he feels a sense of personal investment in the tragedy having 'inherited Hillsborough' growing up in the city. ${ }^{88}$ Elements of such collective victimisation passed down through generations can be seen in relation to London after both the terrorist bombings of 7 July 2005 and the March 2017 attacks, where, on both occasions, comments were made in the media around Londoners drawing on the resilience shown by older generations in that city who lived through the Blitz during World War II. ${ }^{89}$ Indeed, the same sense of collective cultural mourning is now present at an international level in these major cases, reflected by what has become a standardised ritual of national landmarks around the world being adorned in the colours of the 'country' most recently victimised, working down to individuals updating their social media pictures to reflect a sombre meme of support and/or defiance. Associated cultural artefacts have developed, including the 'pray for London' and 'pray for Manchester' meme, where the city is continuously replaced with the location of the most recent highprofile terrorist incident. ${ }^{90}$

\section{Victim culture and the criminal justice processes}

The above examples illustrate both the culturally enthused and politicised nature of the victim issue in the twenty-first century, as well as, crucially, the practical influence such matters are exerting over public policy. As well as in the political realm, the advent of more culturally enthused notions of victimisation discussed above raise significant challenges for the criminal justice system, most notably when attempting to reconcile these seemingly ever-expanding and culturally charged understandings of victimisation with legal and procedural practicalities, especially within the still staunchly adversarial criminal justice system utilised in England and Wales. Such a meeting exposes a fundamental tension between the more constructivist approach outlined by cultural

87 Horrie and Chippindale (n 17).

88 Ciaran Varley, 'I've Inherited Hillsborough ... What It Means To a Scouser Like Me' BBC News (14 April 2017) <http://www.bbc.co.uk/bbcthree/item/1a5e1066-bbb2-464f-9a1a-c03b05ffc127>.

89 Sunny Hundal, 'No Wonder the Far-right was so Quick to Capitalise on the Westminster Terror Attack - It Relies on Atrocities for Support' The Independent (London, 23 March 2017) <http://www.independent.co.uk/voices/westminster-terror-attack-far-right-capitalise-islamist-extremismwhite-nationalism-clash-of-a 7645426.html>.

90 Scarlet Howes, 'Berlin's Brandenburg Gate Turns into Giant Union Jack in Stunning Show of Solidarity with London after Terror Attack' The Mirror (London, 23 March 2017) <http://www.mirror.co.uk/news/uknews/berlins-brandenburg-gate-turns-giant-10086897> 017. 
victimologists and the more positivist understanding of crime, harm and victimisation usually favoured (some would say necessitated) by the legal system.

Delving deeper for a moment into the basic precepts of criminal justice systems (especially adversarial justice systems), it can be quickly gleaned that these systems are not for the most part geared around the notion of victimisation or trauma, including 'vicarious trauma,' 91 being realised and accepted over time. Indeed, the assumption of such systems is that the majority of evidence loses quality rather than improves through prolonged reflection. Witnesses' memories fade and physical evidence degrades, which make it more difficultly to prove a crime (or a victimisation) has occurred to the required high standard as a matter of law. Other factors come into play too, which are illustrated by an examination of domestic violence cases. Domestic violence has long been held as a particularly difficult form of prosecution to achieve, largely due to victims' reluctance to come forward in the first place and, secondly, due to their perceived tendency to change their mind at the door of the courtroom and refuse to give evidence. ${ }^{92}$ Police and prosecutors in many jurisdictions have for several years emphasised the speedy progression of such cases precisely so the main (often only) evidence, the victim's testimony, is not lost. ${ }^{93}$ Interestingly, the temporal component of victimisation therefore works in a different direction in these cases to the examples discussed earlier (such as child sexual abuse) in the sense that, rather than realising their victimisation over time, domestic violence victims might self-define themselves as such initially at the point of reporting to the police, ${ }^{94}$ but come to define themselves differently as time passes.

Nevertheless, from the victims' perspective the cultural discussions outlined above strongly hint that it can matter less what they feel at the 'initial' point of victimisation or at the time of giving a statement to the police. More important to some victims may be their developed impressions and feelings about what has happened to them as they see things when the time comes to give evidence at trial. $\mathrm{I}^{95}$ and others ${ }^{96}$ have previously discussed the concept of narrative and account-making in the experience of victimisation. McGarry and Walklate ${ }^{97}$ speak in terms of 'testimony'. A fundamental division therefore exists between the desire of the criminal justice process for 'evidence' and the victim's desire to 'tell a story', their understanding of which may have developed over time. In adversarial justice, by contrast, any 'development' of what a victim says at the time of trial versus what they said in their initial statement will be held up by the defence as evidence of inconsistency and therefore reduced credibility. In other words, the criminal justice system is specifically engineered to factor out the temporal development of victimisation as an experience. It is not just 'new' stories (in the sense that they are developed stories) that cause difficulties for the traditional criminal justice system. Such a system also has problems with old stories, even if those stories are not

91 Louise Ellison and Vanessa Munro, 'Taking Trauma Seriously: Critical Reflections on the Criminal Justice Process' (2016) 21(3) International Journal of Evidence and Proof 183.

92 Antonia Cretney and Gwynn Davis, 'Prosecuting Domestic Assault: Victims Failing Courts or Courts Failing Victims?’ (1997) 36 Howard Journal of Criminal Justice 146.

93 Dee Cook, Mandy Burton, Amanda Robinson and Christine Vallely, Evaluation of Specialist Domestic Violence Courts/Fast Track Systems (CPS 2004).

94 Albeit, typically, only after such victimising has been ongoing for some time.

95 Matthew Hall, Victims of Crime: Policy and Practice in Criminal Justice (Willan 2009).

96 See Catherine Riessman, 'Making Sense of Marital Violence: One Woman's Narrative' in George C Rosenwald and Richard L Ochberg (eds), Storied Lives: The Cultural Politics of Self-understanding (Yale University Press 1992); Sveinung Sandberg, 'The Importance of Stories Untold: Life-story, Event-story and Trope' (2016) 12(2) Crime, Media, Culture: An International Journal 153.

97 McGarry and Walklate (n 6). 
subject to factual changes. This is most keenly felt with the difficulty in bringing so-called 'cold cases' to justice, even in the light of substantial changes in both the legal and cultural acceptance of various kinds of victimhood discussed. Furthermore, because the law as it was at the time of the commission of an offence will be the law applied when these cases come to trial, a situation develops where this applicable law is many steps behind this modern cultural, and even legal, narrative of victimisation.

In order to illustrate practically the conflicts that occur between the more culturally informed notions of victimisation discussed above and the legal practicalities/requirements of the criminal justice process, I will here turn to another highly publicised case in the UK, that of long-time children's entertainer Rolf Harris. Another noted case arising in the light of the Savile revelations, entertainer Rolf Harris was convicted in 2014 on 12 counts of indecent assault. The crimes occurred across the $1960 \mathrm{~s}, 1970 \mathrm{~s}$ and 1980s against children between the age of 13 and 19. Harris was sentenced to five years and nine months in prison in accordance with sentencing practices in force at the time of the offences. The judge in the case expressly acknowledged both that the activities of Harris would now fall within the definition of more serious offences and that those 'equivalent offences today attract significantly higher maximum sentences'98 (with a potential maximum of 14 years in prison). Again, this reflects the difficulty of ensuring the law continues to reflect changes in culturally prevalent conceptions of victimisation.

In January 2017 Harris was back in court (although appearing via video-link) to face seven further indecent assault charges. The offences allegedly occurred between 1971 and 2004 and involved seven complainants who were aged between 12 and 27 at the time. Coming in the wake of the Savile revelations, both of Harris' trials were cast very much in the same mould by the press. The narrative in each case was of a previously lauded children's entertainer with a predatory side who had cunningly got away with serious crimes by abusing his celebrity status for decades. This itself has become a new 'stereotypical' narrative of victimhood added to the cultural lexicon over recent years. What is noteworthy in this case is that such points have been explicitly raised by Harris' defence team. Hence, in his 2017 trial his barrister noted:

It's difficult to imagine a harder or faster or deeper fall from grace than that suffered by Rolf Harris. ${ }^{99}$

In the reporting of the 2017 case there are stark examples of the prosecution and defence each attempting to convince the jury of their position by respectively advocating or actively challenging this narrative. Hence, the prosecution in the case painted Harris very much in a way that recalls his previous trial and the case of Savile:

It is striking that so many of the allegations involve Mr Harris getting away with a sly, quick grope right under the noses of people who did not notice . . . We suggest that Mr Harris was very good at getting away with it. ${ }^{100}$

Here then is a formulaic characterisation of a sly, 'hiding in plain sight' celebrity with a predatory side. The defence meanwhile was at pains to both challenge this narrative and, indeed, to imply that the cultural embeddedness of this 'standard' story was in fact a deeply prejudicial influence on the jury. Thus, the defence turned attention back to the

$98 R v$ Rolf Harris: Sentencing Remarks of Mr Justice Sweeney, 4 July 2014, at 4 <www.judiciary.gov.uk/wpcontent/uploads/2014/07/sentencing-remarks-mr-j-sweeney-r-v-harris1.pdf $>$.

99 BBC, 'Rolf Harris "vulnerable" to false claims after conviction' BBC News (1 February 2017) <http://www.bbc.co.uk/news/uk-38828332>.

100 Ibid 
complainants in the case, arguing that the jury in the 2014 trial had 'got it wrong' and more so that a 'media frenzy' had made Harris 'vulnerable to people making accusations against him'. 101 The jury in this case ultimately returned verdicts of not guilty for three of the assaults, and were then discharged from deliberating on the further four counts.

Such arguments over the impact of the media attention focused on Harris' trials continued in May 2017 when, at the same time as Harris was being released from prison following his original convictions, he was brought to trial again on the four charges from which the jury had been discharged in the previous proceedings. These were four counts of indecent assault against three teenagers between 1971 and 1983. In this trial, Harris' defence team once again argued that one of the complainants in the case was simply jumping on the 'compensation bandwagon'. ${ }^{102}$ In response, the complainant is reported to have said:

I absolutely have not ... One of the reasons perhaps it was easier for me to tell police is because I had told people over the years. ${ }^{103}$

We can note in this statement a reflection of developing victimhood over time through repeated remaking of a narrative. Ultimately, the jury in this case was unable to reach verdicts on all four charges. The key observation here is that in this ongoing set of cases we have two radically different narrative constructions around the crime of indecent assault. Harris is either a 'Savile-esque' villain portrayed as 'fallen from grace' (a term notable for emoting binary images of good and evil), or he is a victim (in relation to his last two trials) of the modern cultural acceptance of a set narrative concerning a stereotyped victimisation story. The key observation though is that we see in the second and third Harris trials that the cultural prevalence of a set narrative about celebrity abuse led to allegations being made which were not substantiated in court; in cultural terms the reality as defined by the criminal justice process did not always match the prevalent cultural narrative. As such, we might express concern here that an over-reliance on cultural narratives as a basis for assigning victim capital has the potential to breed injustices.

\section{Discussion}

The core implication of the above discussion is that those seeking to understanding victim policy in the contemporary context must become attuned to its dynamic, cultural meanings which are inevitably connected with this endeavour. We have seen how the way the public views and attributes meaning to specific cases can alter over time. Hence, the cultural meanings attributed to the 'Hillsborough Disaster' are infinitely more shaded and complex in 2017 than they were in 1989. Similar developments can be seen in relation to Madeleine McCann's disappearance. In some cases, we see conceptually distinct and contradictory narrative constructions playing out on the public stage. Hence the Ched Evans case either represents a criminal justice system 'gone wrong' and setting dangerous 'precedents' for rape victims, on the one hand, or a triumph of common sense over exacting 'political correctness' on the other. Again, the narrative construction and the 'meanings' attributed to rape victims and their interactions with the criminal justice system have in this case been heavily influenced by media representations, the Ministry of Justice, the judiciary and others. In this we should note in particular the degree to which certain kinds of victims are now facilitated in making very public accounts of their

101 Ibid

102 Ibid.

103 BBC, 'Rolf Harris to be Freed from Stafford Prison on Friday' BBC News (London, 18 May 2017) <http://www.bbc.co.uk/news/uk-39960138>. 
victimisation, notably victims of terrorism, and the cultural phenomena whereby vast swathes of the national and international community are seen as 'standing alongside' those victims. It is also important not to underestimate the significance of the criminal trial itself as the most publicised component of the criminal justice process. We know the majority of people still base much of their opinion of the justice system on knowledge obtained though media portrayals of the trial: both fictional and non-fictional. ${ }^{104}$ Through such means, cultural understandings and 'meanings' become attributed to victims and the criminal justice process which then, as we have seen, through thus acquiring victim capital, goes on to influence public policy.

Such public meanings attributed to different kinds of victims and victimisations are in constant flux and are subject to the influence of competing narratives delivered by a whole range of actors. In recent years, the rise and fall of said narratives have led to sometimes quite dramatic shifts in government policy. Clearly, victim reform cannot be separated from its wider socio-economic and cultural context. As such, it is submitted that understanding and challenging the cultural constructions and meanings attributed to victimisation have become core competencies for modern victimologists. Attributing this full pantheon of interacting cultural narratives concerning victimisation and their impact on public policy to a simple and static notion of 'ideal' or 'politically advantageous' victimhood, is no longer sufficient.

At the same time, the above discussion injects a note of caution when such cultural narratives surrounding victimisation are played out in conjunction with the formal criminal justice process. The Harris case exemplifies the complex questions that are raised both in terms of the apparent inability of the formal criminal justice mechanisms to adapt as quickly to the oscillating and culturally charged notions of victimisation as society in general and to what extent justice mechanisms, notably the standard of proof required to achieve convictions, guard against such narratives promoting 'unjust' outcomes. Of course, many commentators and victim advocates may consider that Harris 'should' have been convicted of his second round of charges and that it is still reflective of a lack of understanding or deference to victims' perspectives that he was not. The complex question that arises from this is to what extent the justice system must guard against becoming hostage to the 'fickle' whims of victim culture and to what extent it must adapt itself to genuine advances in our understanding of what it means to be 'victimised'.

\section{Conclusions}

This paper has sought to ground recent developments in public policy concerning victims of crime in England and Wales in what it sees as much broader and ongoing cultural developments concerning the meanings we as a society attach to the notion of 'victimisation'. In so doing, I have examined whether, from such a perspective, there is evidence that a less positivistic, more culturally attuned notion of victimisation is being recognised in the criminal justice system itself and/or by the various stakeholders and policy actors charged with supporting victims of crime. What we have witnessed in England and Wales (and further afield) since 2010 is an escalation in the development of a socio-political climate in which various, sometimes contradictory, narratives of victimisation constituted by a wide range of official and unofficial actors compete for cultural primacy. When a form of victimisation does achieve such prevalence, this can spur policy actors to quick and decisive action. This culturally informed understanding of

104 Lauren Bradford, 'My Family Was Traumatised First by a Murder, then by the TV Serialisation' The Guardian (London, 2 May 2016) <https://www.theguardian.com/commentisfree/2016/may/02/the-secret-my-familytraumatised-murder-tv-drama-bereaved $>$. 
victim reform arguably offers a more sophisticated tool than the traditional critical or radical approaches, which tend to be based on static ideas of 'ideal' victimhood. Of course, it might be argued that cultural acceptance of various kinds of victimhood, and its manipulation by powerful actors, has arguably only served to create a new breed of 'ideal' victims. Further, we have noted that the challenges to the formal criminal justice process presented by such broader notions of victimhood raise significant questions - in terms of procedural fairness and justice values - which require much further scrutiny. 